\title{
Improving Performance and Competitive Advantage through Innovation and Design of UMKM Products
}

\author{
${ }^{1}$ Tukhas Shilul Imaroh, \\ Universitas Mercu Buana
}

\begin{abstract}
Business competition continues to increase, so that MSMEs must continue to have a competitive advantage and performance. The advantages of an economy are not only derived from technology, let alone natural resources. The latest sources of competitive advantage are product innovation and design. Micro, Small and Medium Enterprises (MSMEs) as part of the economy must also increase their competitiveness by making innovations. Competitive advantage based on innovation and product design should be prioritized because it has durability and a longer period of time. Likewise, the MSME group in West Sumatra tries to preserve local wisdom with various regional characteristics, but still has many limitations including facilities and ideas for business development.
\end{abstract}

The group of wisdom preservation craftsmen is one part of the creative industry sub-sector in the form of the craft creative industry which can be integrated through micro, small, or medium enterprises (MSMEs). This is also directly proportional to the existence of Presidential Regulation Number 28 of 2008 concerning National Industrial Policy which is also regulates the creative industry for the development and determination of the guideline map. Therefore this research aims to improve the performance and competitive advantage of MSMEs through innovation and product design. This research is included in TKT 2, namely formulating the concept of technology and its application to the object of UMKM

Keywords:- Performance, Competitive Advantages of MSMEs, Innovation, and Product Design.

\section{INTRODUCTION}

In the global era, it is necessary to encourage every community in Indonesia to be able to compete through several sectors including the industrial sector based on local wisdom. In advancing the competence of regional resources, local governments need to understand and formulate optimal policies in the empowerment of the people's economy even though it is not an easy job.

Increasingly tighter competition and a decline in sales growth. This needs to be observed and addressed so that the business world can continue to grow and increase. Every business must have a competitive advantage, in order to survive and run well.

MSMEs represent $99.99 \%$ of domestic business actors. More populist welfare. This consequence is a

\author{
${ }^{2}$ Katri Widiyani \\ Institut Teknologi Indonesia
}

necessity that brings big hope. The contribution of MSMEs has high potential because of its large population, as many as 62.92 million business actors based on data for 2017 . The details are 62.10 million micro-enterprises, 757,090 small businesses, and 58,627 medium-sized businesses. Meanwhile, data for 2016 shows that there are 61.65 million MSMEs. The details are 60.86 million micro enterprises, 731,047 small businesses and 56,551 medium enterprises. They have the potential to make moves that make Indonesia's economy grow.

MSMEs should be considered to support the economy. The total employment in 2017 was 120.26 million, consisting of 107.23 million micro enterprises, 5.7 million small businesses, and 3.73 million medium enterprises. Meanwhile, the total employment in 2016 was 116.27 million, consisting of 103.83 million micro enterprises, 5.4 million small businesses, and 3.58 million medium enterprises. MSMEs have a very large market share in Indonesia, especially export-oriented MSMEs. MSMEs are expected to be able to produce import substitution goods which have been burdening the trade balance which is still the government's big thought. Middle class supply chains including MSMEs are also potentially affected. It is different from 1998 when MSMEs were relatively untouched by the exchange rate. They do not have loans in foreign currency so they are isolated from exchange rate fluctuations.

Indonesia and its various business actors have learned a lot from various crises that have caused the business cycle to weaken, namely the $1998,2003,2005$, and 2008 crises. These crises caused business actors to be relatively responsive in any crisis situation. Referring to these conditions, many parties believe that this year Indonesia can grow by $5.3 \%$. When a country's economy is good it is usually followed by inflation.

The Indonesian government continues to encourage Indonesian MSMEs to upgrade their grades. Recorded from a total of 64.2 million MSMEs in Indonesia and contributed 60.34 to the national GDP. The Minister of Cooperatives and Small and Medium Enterprises said that to boost and support MSMEs in graduating, there are five policy directions undertaken by the government.

MSMEs role maph for the next three years is expected to increase significantly. In 2020, it is expected that the export potential of MSMEs is 18.12 percent, the GDP of MSMEs will increase to 61 percent, the national entrepreneurship ratio is 3.55 percent and the realization of modern cooperatives as many as 25 units. In 2021, the 
export potential of MSMEs is 21.14 percent, the GDP of MSMEs will increase by 62 percent, the national entrepreneurial ratio is 4.05 percent and the realization of modern cooperatives is 50 units. At least in terms of exports, we can increase in 2024 by the number of Malaysian exports this year and hopefully if we work together and coordinate we can be optimistic that Indonesian MSMEs can move up in class. Kompas.com 09/12/2019.

Growth and development in this case means that business units that are currently classified as MSMEs are expected to have an increasingly large industrial scale, meaning that business units that are in the micro category are expected to turn into small businesses. Likewise, business units that are currently in the small business category are expected to increase into medium business units, while medium business units can develop into largescale business units. This business development concept can be classified as a form of enterprise upgrading

\begin{tabular}{|lrrcrl|}
\hline Kec/Kriteria & Small & Medium & Micro & \multicolumn{2}{l|}{ Grand Total } \\
\hline ABTB & 535 & \multicolumn{2}{c}{$2,0922,627$} & \\
\hline Guguk Panjang & 2,286 & 144 & 5,024 & 7,454 \\
\hline MandianginKoto & 1,141 & 3 & \multicolumn{2}{l}{3,202} & 4,346 \\
\hline Grand Total & 3,962 & 147 & \multicolumn{2}{c}{10,318} & 14,427 \\
\hline
\end{tabular}

Table 1:- Number of Small and Medium Enterprises (MSMEs)

Bukittinggi City Trade in 2017

Source: Department of Cooperatives, UKM and Bukittinggi City Trade in 2017

Many MSMEs do not develop in running their businesses because of the lack of product innovation, so that many businesses only last for 1-2 years, then go bankrupt because the products or services offered are unable or unable to compete. There are still many MSME players in Indonesia who only run businesses on a followup basis without seeing their own potential. This condition will show that there are still a few local MSME products that have succeeded in penetrating the international market, including the MSMEs craftsmen in Bukittinggi.

MSMEs players are expected to be able to think critically and be innovative in producing goods and services. Even though the goods offered are the same, if each has a significant difference, it will make consumers have many choices.

The table shows the development of Bukit Tinggi MSMEs from a growing quantity in terms of numbers.

This research was conducted at MSMEs in Bukittinggi, West Sumatra according to the explanation in the background section which aims as follows:

$>$ Knowing and analyzing the effect of product innovation on improving the performance of MSMEs

$>$ Knowing and analyzing the effect of product design on improving the performance of MSMEs.
Knowing and analyzing the effect of product innovation on the competitive advantage of MSME products

$>$ Knowing and analyzing the effect of product design on the competitive advantage of MSME products

$>$ Knowing and analyzing the effect of MSME performance on the competitive advantage of MSME products

\section{LITERATURE REVIEW}

According to Dobele \& Pietere (2015), there are several factors that influence competitive advantage, namely: (i) value, namely, a company must know what value or value the prospective buyer wants or expects, according to or not with their expectations, or according to or not with what they get from the company's products; (ii) ability to deliver products, including speed, product delivery and customer sensitivity; (iii) whether or not the price set by the company for its products is appropriate in the eyes of consumers or buyers of said products; (iv) consumer loyalty, namely, the creation of a group of buyers in the market (segment) who will ignore substitute products from competitors, in other words, the existence of loyal customers or loyal customers (customer loyalty). The increasing number of companies that concentrate on the business and market, it means they have a big advantage.

Eniola \& Ektebang (2015) suggest two basic types of competitive advantage that companies can have, namely low cost or differentiation. Two types of competitive advantage combined with the scope of activities that the company wants to achieve, produce three generic strategies for achieving average performance in an industry, namely cost leadership, differentiation, and focus. The focus strategy has two variants, a cost focus and a differentiation focus, namely: (i) cost leadership, that is, in a company that is determined to become a low-cost producer in its industry; (ii) differentiation, that is, a company strives to be unique in its industry along several dimensions that are widely valued by buyers; (iii) focus, namely, the focus strategy has two variants, including cost focus, the company seeks cost advantage in its target segment and focus differentiation, the company seeks differentiation in its target segment.

\section{$>$ Product innovation}

Innovation is part of the factors that determine competitive advantage. The similarity in appearance of similar products and systems of similar companies from competitors is a driving factor for innovation, usually competing products appear without experiencing significant changes and even tend to be static. This situation can be profitable, because the competition that arises from the emergence of competitor products can be overcome by making product innovations. Apart from product innovation, systems within the company also need innovation. Innovation is something that can be seen as a functional progress that can take it one step ahead of competitors, if it has an advantage that is seen as added value for consumers. 
According to Kotler \& Keller (2016: 454), the dimensions of product innovation include: 1 . New products for the world; 2. Improvement of existing products; 3. New product lines; 4 . Additions to existing product lines.

Robbins and Coulter (2010) Innovation is the process of turning creative ideas into useful products or work methods. (Kasali 2010) explains that innovation is the ability to see things in a new and sometimes out of the ordinary way. (Anshori 2010) argues that innovation is the sum of the why and how questions.

West \& Far (Ancok, 2012: 34) Innovation is the deliberate introduction and application of new ideas, processes, products and procedures to the units that implement them, which are designed to benefit individuals, groups, organizations and society at large.

\section{$>$ Product design}

Product design is one of the main factors that become consumers' considerations in choosing batik because the design of a product will affect appearance, as suggested by Kotler that design is the totality of features that affect the appearance and function of a product in terms of consumer needs (Kotler, 2005: 332 ).

Products designed by handicraft products generally focus more on the values of uniqueness, aesthetics (beauty), art (art), superiority, high dignity, special, distinctive, and refined taste as basic elements. Meanwhile, in fulfilling its function, it emphasizes the fulfillment of wear functions that are more physical (physiological), for example: wearing objects, jewelry, furniture, or clothing (Palgunadi, 2007: 32).

Another design concept is the totality of features that affect the appearance, taste and function of a product based on customer needs (Kotler and Keller, 2009: 11). Design is more than just an outer shell, it is the heart of a product. Good design is judged by a deep understanding of customer needs. More than just creating attributes for a product or service, design involves building a product experience for the customer.

Kotler and Armstrong (2014: 254) product design is a concept that is bigger than style. Style only describes the appearance of the product. Style can be attractive or boring. A sensational style can grab attention and produce a beautiful aesthetic, but it doesn't really make a product perform any better. Unlike style, design is not just the skin, design is the heart of the product". Based on the above definition, the researcher came to the understanding that product design is anything that must be taken into account by the seller to stimulate someone's buying interest, even leading to a purchase decision

Product Design Dimensions Kotler and Armstrong (2014: 255) state that there are seven design or design aspects which include shape, features, quality, durability, reliability, easy repair and style. The following is an explanation of these aspects: 1. Shape: Many products can be differentiated by shape, model size 2. Features: Most products can be offered with different features that complement the basic functions of the product. Attempts to be the first to introduce new features that are considered valuable is one of the most effective ways to compete. 3. Quality: Buyers expect products to have quality conformity to high standards and specifications. The conformity quality is the level of conformity and fulfillment of all units produced against the promised target specifications. 4. Durability: A measure of the expected life span of the product under normal conditions. Is a valuable attribute for certain products. 5. Reliability: Buyers will generally buy more to get a more reliable product. Reliability is a measure of profitability that a particular product will not break or fail within a certain period of time. 6. Easy to repair: buyers buy products that are easy to repair. Ease of repair is a measure of the ease with which a product can be repaired when the product is damaged. 7. Style (style): Describes the appearance and feelings of the product for the buyer

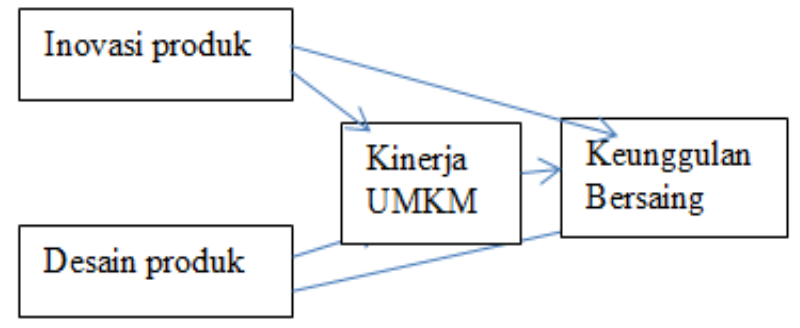

Fig 1:- Thinking Framework

\section{$>$ Hypotheses}

Hypotheses are intended as initial answers to the problems at hand. The hypothesis in this study is formulated as follows:

- There is a positive and significant influence between product innovation on improving the performance of MSMEs

- There is a positive and significant influence between product design on improving the performance of MSMEs.

- There is a positive and significant influence between product innovation on the competitive advantage of MSMEs products

- There is a positive and significant influence between product design on the competitive advantage of MSMEs products

- There is a positive and significant influence between the performance of MSMEs on the competitive advantage of MSMEs products

\section{$>$ Research Methods}

This research is included in research with a survey method conducted in Bukit Tinggi MSMEs, West Sumatra.

Independent variable (X) / exogenous, is a variable that affects the dependent variable, product innovation (X1), and product design (X2), the dependent variable (Y) / endogenous, in this study, which becomes the variable, namely the performance of MSMEs (Y1), and Competitive Advantage (Y2). 
The population in this study were all MSMEs groups registered at the Bukit Tinggi MSMEs office - West Sumatra, with the method used to determine the number of samples carried out by quota sampling with criteria, MSMEs groups producing food, beverages, borders, and embroidery.
The verification analysis in this study used a statistical test tool, namely the variance-based structural equation test or better known as the Partial Least Square (PLS) using the Smart PLS 3.2.7 software.

\begin{tabular}{|c|c|c|}
\hline KARATERISTIK & JUMLAH (ORANG) & PRESENTASE \\
\hline \multicolumn{3}{|c|}{ JENIS KELAMIN (Sex) } \\
\hline Laki-laki / Male & 29 & $60 \%$ \\
\hline Perempuan/ Female & 19 & $40 \%$ \\
\hline \multicolumn{3}{|c|}{ USIA (Age) } \\
\hline $25-30$ tahun $(\mathrm{Y})$ & 2 & $4 \%$ \\
\hline $31-35$ tahun $(Y)$ & 6 & $13 \%$ \\
\hline $36-40$ tahun $(\mathrm{Y})$ & 13 & $27 \%$ \\
\hline $41-45$ tahun $(Y)$ & 13 & $27 \%$ \\
\hline $\begin{array}{c}46-50 \text { tahun }(\mathrm{Y}) \\
51 \text { tahu }(\mathrm{Y}) \leq\end{array}$ & $\begin{array}{c}10 \\
4\end{array}$ & $\begin{array}{l}21 \% \\
8 \%\end{array}$ \\
\hline \multicolumn{3}{|c|}{ PENDIDIKAN (Education) } \\
\hline $\begin{array}{l}\text { SMP (Junior High School) } \\
\text { SMA (Senior High Scholl) } \\
\text { D3 -S1 (Under /Graduate) }\end{array}$ & $\begin{array}{c}5 \\
29 \\
14 \\
\end{array}$ & $\begin{array}{l}11 \% \\
60 \% \\
29 \% \\
\end{array}$ \\
\hline \multicolumn{3}{|c|}{ JENIS USAHA (Type of Production) } \\
\hline $\begin{array}{c}\text { Makanan (Food) \& minuman (Baverages) } \\
\text { Border \& Craft } \\
\text { wiraswasta sembako } \\
\text { lain-lain }\end{array}$ & $\begin{array}{c}12 \\
21 \\
10 \\
5\end{array}$ & $\begin{array}{l}25 \% \\
44 \% \\
21 \% \\
10 \%\end{array}$ \\
\hline
\end{tabular}

Table 2:- Respondent Description

Source: Processed questionnaire data

\section{Research Descriptive}

This research as an object is UMKM which represents the area in Bukit Tinggi district as many as 48 people, based on demographic data, namely: gender, age, education, type of Production.

\begin{tabular}{|c|c|}
\hline Interval & Kategori \\
\hline $1,00-1,80$ & Sangat tidak baik \\
\hline $1,81-2,60$ & Tidak baik \\
\hline $2,61-3,40$ & Cukup \\
\hline $3,41-4,20$ & Baik \\
\hline $4,21-5,00$ & Sangat baik \\
\hline
\end{tabular}

\section{Respondents' Responses}

In order to analyze each question or indicator, it is done by calculating the frequency of answers to each category (answer choices) and adding them up. After each indicator has a number, the researcher then draws a city line.
NJI (Interval cascade value $)=($ Highest score-lowest score) / (Number of question criteria)

After the average value, the answer is known, then the results are interpreted by means of a continuum table, which is as follows:

Minimum index: 1

Maximum index: 5

Interval: 4

Interval distance: $(5-1): 5=0.8$

The following are the categories for each variable:

\begin{tabular}{|l|l|l|l|c|}
\hline Sangat tidak baik & Tidak baik & Cukup & Baik & $\begin{array}{c}\text { Sangaat } \\
\text { baik }\end{array}$ \\
\hline $\mathbf{1 , 0 0}$ & $\mathbf{1 , 8 0}$ & $\mathbf{2 , 6 0} \quad \mathbf{3 , 4 0}$ & $\mathbf{4 , 2 0}$ & $\mathbf{5 , 0 0}$
\end{tabular}

Fig 2:- Continuum line

Referring to the table above, each variable is categorized as follows: 
The following is an explanation of each variable:

\begin{tabular}{|c|c|c|c|c|c|c|c|}
\hline \multirow{2}{*}{$\begin{array}{c}\text { Indi } \\
\text { kator }\end{array}$} & \multicolumn{5}{|c|}{ Pilihan Jawaban } & \multirow{2}{*}{ Skor } & \multirow{2}{*}{ Mean } \\
\hline & 1 & 2 & 3 & 4 & 5 & & \\
\hline \multirow{2}{*}{ KPB1 } & 2 & 2 & 7 & 22 & 15 & \multirow{2}{*}{190} & \multirow{2}{*}{3,96} \\
\hline & $4,2 \%$ & $4,2 \%$ & $14,6 \%$ & $45,8 \%$ & $31,3 \%$ & & \\
\hline \multirow{2}{*}{ KPB2 } & 5 & 11 & 13 & 11 & 8 & \multirow{2}{*}{150} & \multirow{2}{*}{3,13} \\
\hline & $10,4 \%$ & $22,9 \%$ & $27,1 \%$ & $22,9 \%$ & $16,7 \%$ & & \\
\hline \multirow{2}{*}{ KPB3 } & 2 & 5 & 5 & 13 & 23 & \multirow{2}{*}{194} & \multirow{2}{*}{4,04} \\
\hline & $4,2 \%$ & $10,4 \%$ & $10,4 \%$ & $27,1 \%$ & $47,9 \%$ & & \\
\hline \multirow{2}{*}{ KPB4 } & 3 & 2 & 7 & 21 & 15 & \multirow{2}{*}{187} & \multirow{2}{*}{3,90} \\
\hline & $6,3 \%$ & $4,2 \%$ & $14,6 \%$ & $43,8 \%$ & $31,3 \%$ & & \\
\hline \multirow{2}{*}{ KPB5 } & 2 & 2 & 5 & 23 & 16 & \multirow{2}{*}{193} & \multirow{2}{*}{4,02} \\
\hline & $4,2 \%$ & $4,2 \%$ & $10,4 \%$ & $47,9 \%$ & $33,3 \%$ & & \\
\hline \multirow{2}{*}{ KPB6 } & 2 & 1 & 10 & 21 & 14 & \multirow{2}{*}{188} & \multirow{2}{*}{3,92} \\
\hline & $4,2 \%$ & $2,1 \%$ & $20,8 \%$ & $43,8 \%$ & $29,2 \%$ & & \\
\hline \multirow{2}{*}{ KPB7 } & 2 & 2 & 8 & 24 & 12 & \multirow{2}{*}{186} & \multirow{2}{*}{3,88} \\
\hline & $4,2 \%$ & $4,2 \%$ & $16,7 \%$ & $50,0 \%$ & $25,0 \%$ & & \\
\hline \multirow{2}{*}{ KPB8 } & 4 & 3 & 18 & 14 & 9 & \multirow{2}{*}{165} & \multirow{2}{*}{3,44} \\
\hline & $8,3 \%$ & $6,3 \%$ & $37,5 \%$ & $29,2 \%$ & $18,8 \%$ & & \\
\hline \multicolumn{6}{|c|}{ Total } & 1453 & 3,78 \\
\hline
\end{tabular}

Table 3:- (The table above illustrates the responses of respondents regarding the Product Competitive Advantage (KBP))

The table above illustrates the responses of respondents regarding the Product Competitive Advantage (KBP) variable. Based on the processing results presented in the table above, it can be seen that the total score for the Product Competitive Advantage Variable (KBP) is 1453, with an average of 3.78. This value is based on the continuum line in the range from 3.40 to 4.20 , so it is stated that the Product Competitive Advantage (KBP) variable is in the Good category.

\begin{tabular}{|c|c|c|c|c|c|c|c|}
\hline \multirow{2}{*}{$\begin{array}{c}\text { Indi } \\
\text { kator }\end{array}$} & \multicolumn{5}{|c|}{ Pilihan Jawaban } & \multirow{2}{*}{ Skor } & \multirow{2}{*}{ Mean } \\
\hline & 1 & 2 & 3 & 4 & 5 & & \\
\hline \multirow{2}{*}{$\mathrm{K} 1$} & 1 & 1 & 12 & 22 & 12 & \multirow{2}{*}{187} & \multirow{2}{*}{3,90} \\
\hline & $2,1 \%$ & $2,1 \%$ & $25,0 \%$ & $45,8 \%$ & $25,0 \%$ & & \\
\hline \multirow{2}{*}{$\mathrm{K} 2$} & 1 & 1 & 8 & 26 & 12 & \multirow{2}{*}{191} & \multirow{2}{*}{3,98} \\
\hline & $2,1 \%$ & $2,1 \%$ & $16,7 \%$ & $54,2 \%$ & $25,0 \%$ & & \\
\hline \multirow{2}{*}{$\mathrm{K} 3$} & 1 & 1 & 6 & 28 & 12 & \multirow{2}{*}{193} & \multirow{2}{*}{4,02} \\
\hline & $2,1 \%$ & $2,1 \%$ & $12,5 \%$ & $58,3 \%$ & $25,0 \%$ & & \\
\hline \multirow{2}{*}{ K4 } & 1 & 2 & 12 & 18 & 15 & \multirow{2}{*}{188} & \multirow{2}{*}{3,92} \\
\hline & $2,1 \%$ & $4,2 \%$ & $25,0 \%$ & $37,5 \%$ & $31,3 \%$ & & \\
\hline \multirow{2}{*}{ K5 } & 1 & 2 & 8 & 21 & 16 & \multirow{2}{*}{193} & \multirow{2}{*}{4,02} \\
\hline & $2,1 \%$ & $4,2 \%$ & $16,7 \%$ & $43,8 \%$ & $33,3 \%$ & & \\
\hline \multirow{2}{*}{ K6 } & 1 & 2 & 5 & 26 & 14 & \multirow{2}{*}{194} & \multirow{2}{*}{4,04} \\
\hline & $2,1 \%$ & $4,2 \%$ & $10,4 \%$ & $54,2 \%$ & $29,2 \%$ & & \\
\hline \multirow{2}{*}{$\mathrm{K} 7$} & 1 & 3 & 5 & 22 & 17 & \multirow{2}{*}{195} & \multirow{2}{*}{4,06} \\
\hline & $2,1 \%$ & $6,3 \%$ & $10,4 \%$ & $45,8 \%$ & $35,4 \%$ & & \\
\hline \multicolumn{6}{|c|}{ Total } & 1341 & 3,99 \\
\hline
\end{tabular}

Table 4:- Respondents' Responses Regarding MSME Business Performance Variables (K) 
ISSN No:-2456-2165

Table di atas menggambarkan tanggapan responden mengenai Variabel Kinerja Usaha (K). Berdasarkan hasil pengolahan yang disajikan pada tabel di atas, dapat dilihat bahwa skor total untuk Variabel Kinerja Usaha UMKM (K) adalah 1341. Dengan rata-rata 3,99 nilai tersebut dimasukkan ke dalam garis kontinum sebagai berikut:

The table above illustrates the responses of respondents regarding the Business Performance Variable (K). Based on the processing results presented in the table above, it can be seen that the total score for the MSME Business Performance Variable (K) is 1341. With an average of 3.99 this value is entered into the continuum line as follow

$(3,99)$

\begin{tabular}{|l|l|l|l|l|}
\hline Sangat tidak baik & Tidak baik & Cukup & Baik & $\begin{array}{l}\text { Sangaat } \\
\text { baik }\end{array}$ \\
\hline $\mathbf{1 , 0 0} \mathbf{1 , 8 0}$ & $\mathbf{2 , 6 0} \mathbf{3 , 4 0} \mathbf{4 , 2 0}$ & $\mathbf{5 , 0 0}$ \\
& Fig 3:- Continuum line
\end{tabular}

Based on the table above, the average value of the SME Business Performance Variable $(K)$ is in the range 3.40-4.20 so it is stated that the MSME Business Performance $(\mathrm{K})$ variable is in the Good category.

\begin{tabular}{|c|c|c|c|c|c|c|c|}
\hline \multirow{2}{*}{$\begin{array}{l}\text { Indi } \\
\text { kator }\end{array}$} & \multicolumn{5}{|c|}{ Pilihan Jawaban } & \multirow{2}{*}{ Skor } & \multirow{2}{*}{ Mean } \\
\hline & 1 & 2 & 3 & 4 & 5 & & \\
\hline \multirow{2}{*}{ IP1 } & 1 & 1 & 7 & 17 & 22 & \multirow{2}{*}{202} & \multirow{2}{*}{4,21} \\
\hline & $2,1 \%$ & $2,1 \%$ & $14,6 \%$ & $35,4 \%$ & $45,8 \%$ & & \\
\hline \multirow{2}{*}{ IP2 } & 1 & 1 & 4 & 19 & 23 & \multirow{2}{*}{206} & \multirow{2}{*}{4,29} \\
\hline & $2,1 \%$ & $2,1 \%$ & $8,3 \%$ & $39,6 \%$ & $47,9 \%$ & & \\
\hline \multirow{2}{*}{ IP3 } & 1 & 1 & 5 & 23 & 18 & \multirow{2}{*}{200} & \multirow{2}{*}{4,17} \\
\hline & $2,1 \%$ & $2,1 \%$ & $10,4 \%$ & $47,9 \%$ & $37,5 \%$ & & \\
\hline \multirow{2}{*}{ IP4 } & 1 & 2 & 12 & 20 & 13 & \multirow{2}{*}{186} & \multirow{2}{*}{3,88} \\
\hline & $2,1 \%$ & $4,2 \%$ & $25,0 \%$ & $41,7 \%$ & $27,1 \%$ & & \\
\hline \multirow{2}{*}{ IP5 } & 1 & 2 & 8 & 19 & 18 & \multirow{2}{*}{195} & \multirow{2}{*}{4,06} \\
\hline & $2,1 \%$ & $4,2 \%$ & $16,7 \%$ & $39,6 \%$ & $37,5 \%$ & & \\
\hline \multicolumn{6}{|c|}{ Total } & 989 & 4,12 \\
\hline
\end{tabular}

Table 5:- Responses of respondents regarding Product Innovation Variables (IP)

The table above illustrates the responses of respondents regarding Product Innovation Variables (IP). Based on the processing results presented in the table above, it can be seen that the total score for the Product Innovation Variable (IP) is 989.With an average of 4.12 this value is entered into the continuum line as follows:
$(4,12)$

\begin{tabular}{|l|l|l|l|l|}
\hline Sangat tidak baik & Tidak baik & Cukup & Baik & $\begin{array}{l}\text { Sangaat } \\
\text { baik }\end{array}$ \\
\hline $\mathbf{1 , 0 0} \mathbf{1 , 8 0}$ & $\mathbf{2 , 6 0} \quad \mathbf{3 , 4 0} \quad \mathbf{4 , 2 0}$ & $\mathbf{5 , 0 0}$ \\
& Fig 4:- Continuum line
\end{tabular}

Based on the table above, the average value of Product Innovation Variable (IP) is in the range 3.40-4.20 so it is stated that the Product Innovation (IP) variable is in the Good category.

\begin{tabular}{|c|c|c|c|c|c|c|c|}
\hline \multirow{2}{*}{$\begin{array}{l}\text { Indi } \\
\text { kator }\end{array}$} & \multicolumn{5}{|c|}{ Pilihan Jawaban } & \multirow[t]{2}{*}{ Skor } & \multirow[t]{2}{*}{ Mean } \\
\hline & $\mathbf{1}$ & 2 & 3 & 4 & 5 & & \\
\hline \multirow{2}{*}{ DP1 } & 1 & 2 & 6 & 24 & 15 & \multirow{2}{*}{194} & \multirow{2}{*}{4,04} \\
\hline & $2,1 \%$ & $4,2 \%$ & $12,5 \%$ & $50,0 \%$ & $31,3 \%$ & & \\
\hline \multirow{2}{*}{$\mathrm{DP} 2$} & 1 & 2 & 5 & 23 & 17 & \multirow{2}{*}{197} & \multirow{2}{*}{4,10} \\
\hline & $2,1 \%$ & $4,2 \%$ & $10,4 \%$ & $47,9 \%$ & $35,4 \%$ & & \\
\hline \multirow{2}{*}{ DP3 } & 1 & 3 & 6 & 25 & 13 & \multirow{2}{*}{190} & \multirow{2}{*}{3,96} \\
\hline & $2,1 \%$ & $6,3 \%$ & $12,5 \%$ & $52,1 \%$ & $27,1 \%$ & & \\
\hline \multirow{2}{*}{ DP4 } & 1 & 2 & 5 & 23 & 17 & \multirow{2}{*}{197} & \multirow{2}{*}{4,10} \\
\hline & $2,1 \%$ & $4,2 \%$ & $10,4 \%$ & $47,9 \%$ & $35,4 \%$ & & \\
\hline \multirow{2}{*}{ DP5 } & 1 & 2 & 5 & 20 & 20 & \multirow{2}{*}{200} & \multirow{2}{*}{4,17} \\
\hline & $2,1 \%$ & $4,2 \%$ & $10,4 \%$ & $41,7 \%$ & $41,7 \%$ & & \\
\hline \multirow{2}{*}{ DP6 } & 1 & 1 & 6 & 22 & 18 & \multirow{2}{*}{199} & \multirow{2}{*}{4,15} \\
\hline & $2,1 \%$ & $2,1 \%$ & $12,5 \%$ & $45,8 \%$ & $37,5 \%$ & & \\
\hline \multirow{2}{*}{ DP7 } & 1 & 1 & 6 & 20 & 20 & \multirow{2}{*}{201} & \multirow{2}{*}{4,19} \\
\hline & $2,1 \%$ & $2,1 \%$ & $12,5 \%$ & $41,7 \%$ & $41,7 \%$ & & \\
\hline \multicolumn{6}{|c|}{ Total } & 1378 & 4,10 \\
\hline
\end{tabular}

Table 6:- Respondents' Responses Regarding Product Design Variables (DP) 
The table above illustrates the responses of respondents regarding Product Design Variables (DP). Based on the processing results presented in the table above, it can be seen that the total score for the Product Design Variable (DP) is 1378 . With an average of 4.10 this value is entered into the continuum line as follows:

(4.11)

\begin{tabular}{|l|l|l|l|l|}
\hline Sangat tidak baik & Tidak baik & Cukup & Baik & $\begin{array}{l}\text { Sangaat } \\
\text { baik }\end{array}$ \\
\hline $\mathbf{1 , 0 0} \mathbf{1 , 8 0}$ & $\begin{array}{c}\mathbf{2 , 6 0} \mathbf{3 , 4 0} \mathbf{4 , 2 0} \\
\text { Fig 5:- Continum line }\end{array}$
\end{tabular}

Based on the table above, the average value of Product Design Variable (DP) is in the range 3.40-4.20 so it is stated that the Product Design variable (DP) is in the Good category.

\section{Evaluate the outer model}

The measurement model for the validity and reliability test, the model determination coefficient and the path coefficient for the equation model can be seen in the following figure:

\section{Data analysis}

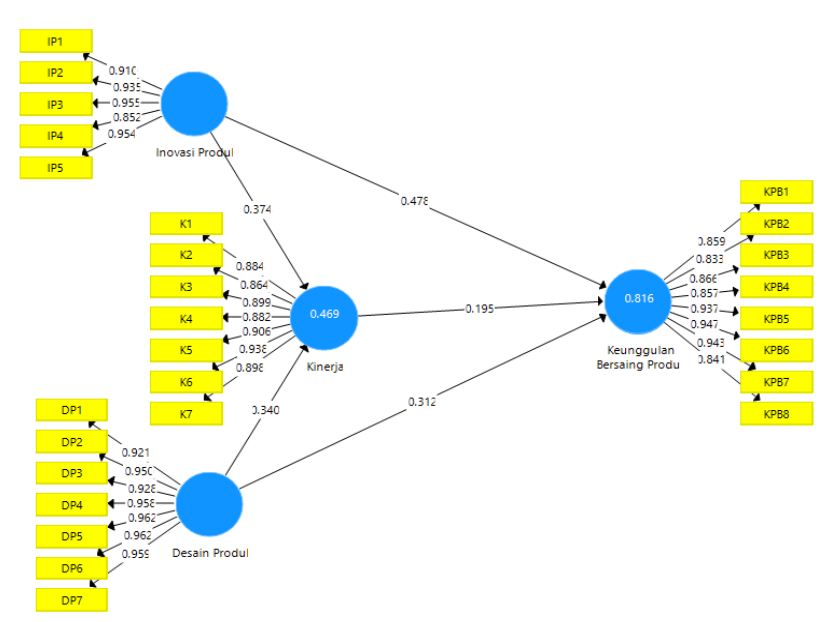

Fig 6:- Measurement model

\section{Loading factor}

\begin{tabular}{|c|c|c|c|c|}
\hline Variabel & Indikator & Outer loading & Titik kritis & Kesimpulan \\
\hline \multirow{7}{*}{$\begin{array}{c}\text { Desain Produk (DP) /Design } \\
\text { Product }\end{array}$} & DP1 & 0,921 & 0,5 & Valid \\
\hline & DP2 & 0,950 & 0,5 & Valid \\
\hline & DP3 & 0,928 & 0,5 & Valid \\
\hline & DP4 & 0,958 & 0,5 & Valid \\
\hline & DP5 & 0,965 & 0,5 & Valid \\
\hline & DP6 & 0,962 & 0,5 & Valid \\
\hline & DP7 & 0,959 & 0,5 & Valid \\
\hline \multirow{5}{*}{$\begin{array}{l}\text { Inovasi Produk (IP)/ Product } \\
\text { Inovation }\end{array}$} & IP1 & 0,910 & 0,5 & Valid \\
\hline & IP2 & 0,935 & 0,5 & Valid \\
\hline & IP3 & 0,955 & 0,5 & Valid \\
\hline & IP4 & 0,852 & 0,5 & Valid \\
\hline & IP5 & 0,954 & 0,5 & Valid \\
\hline \multirow{7}{*}{$\begin{array}{c}\text { Kinerja Usaha }(\mathrm{K}) / \text { Business } \\
\text { Performance }\end{array}$} & K1 & 0,884 & 0,5 & Valid \\
\hline & $\mathrm{K} 2$ & 0,864 & 0,5 & Valid \\
\hline & K3 & 0,899 & 0,5 & Valid \\
\hline & K4 & 0,882 & 0,5 & Valid \\
\hline & K5 & 0,906 & 0,5 & Valid \\
\hline & K6 & 0,938 & 0,5 & Valid \\
\hline & K7 & 0,898 & 0,5 & Valid \\
\hline \multirow{8}{*}{$\begin{array}{c}\text { Keunggulan Bersaing Produk } \\
\text { (KBP)/ Product Competitive } \\
\text { Advantage }\end{array}$} & KPB1 & 0,859 & 0,5 & Valid \\
\hline & KPB2 & 0,833 & 0,5 & Valid \\
\hline & KPB3 & 0,866 & 0,5 & Valid \\
\hline & KPB4 & 0,857 & 0,5 & Valid \\
\hline & KPB5 & 0,937 & 0,5 & Valid \\
\hline & KPB6 & 0,947 & 0,5 & Valid \\
\hline & KPB7 & 0,943 & 0,5 & Valid \\
\hline & KPB8 & 0,841 & 0,5 & Valid \\
\hline
\end{tabular}

Table 7:- Loding factor

Based on the table above, the convergent validity of the measurement model using the loading factor shows that all indicators have a factor loading value greater than 0.5 . So it can be concluded that all indicators are valid. 
Convergent validity

\begin{tabular}{|c|c|}
\hline Variabel & AVE \\
\hline Desain Produk (DP)/ Design Product & 0,900 \\
\hline Inovasi Produk (IP)/ Product Inovation & 0,850 \\
\hline $\begin{array}{c}\text { Keunggulan Bersaing Produk (KBP)/ Product } \\
\text { Competitive Advantage }\end{array}$ & 0,786 \\
\hline Kinerja Usaha (K) / Business Performance & 0,803 \\
\hline
\end{tabular}

$$
\text { Table 8:- AVE }
$$

Convergent validity of the measurement model using the AVE value. Based on the table above, the constructs of $\mathrm{DP}, \mathrm{IP}, \mathrm{K}$, and KBP have AVE values that are greater than 0.5 , so it is concluded that the convergent validity is good.

\section{Discriminant validity}

Discriminant validity testing is done to prove whether the indicator in a construct will have the greatest cross loading value on its construct compared to other constructs. It can be seen in the following table:

\begin{tabular}{|c|c|c|c|c|}
\hline & DP & IP & K & KBP \\
\hline DP1 & 0,921 & 0,797 & 0,539 & 0,793 \\
\hline DP2 & 0,950 & 0,786 & 0,620 & 0,841 \\
\hline DP3 & 0,928 & 0,724 & 0,596 & 0,770 \\
\hline DP4 & 0,958 & 0,832 & 0,630 & 0,810 \\
\hline DP5 & 0,962 & 0,821 & 0,614 & 0,796 \\
\hline DP6 & 0,962 & 0,801 & 0,665 & 0,771 \\
\hline DP7 & 0,959 & 0,802 & 0,670 & 0,795 \\
\hline IP1 & 0,804 & 0,910 & 0,640 & 0,787 \\
\hline IP2 & 0,783 & 0,935 & 0,588 & 0,778 \\
\hline IP3 & 0,806 & 0,955 & 0,543 & 0,821 \\
\hline IP4 & 0,683 & 0,852 & 0,607 & 0,787 \\
\hline IP5 & 0,784 & 0,954 & 0,654 & 0,825 \\
\hline K1 & 0,457 & 0,438 & 0,884 & 0,556 \\
\hline K2 & 0,613 & 0,634 & 0,864 & 0,683 \\
\hline K3 & 0,683 & 0,691 & 0,899 & 0,691 \\
\hline K4 & 0,586 & 0,613 & 0,882 & 0,613 \\
\hline K5 & 0,618 & 0,594 & 0,906 & 0,656 \\
\hline K6 & 0,564 & 0,602 & 0,938 & 0,674 \\
\hline K7 & 0,535 & 0,511 & 0,898 & 0,569 \\
\hline KPB1 & 0,687 & 0,766 & 0,604 & 0,859 \\
\hline KPB2 & 0,629 & 0,717 & 0,592 & 0,833 \\
\hline KPB3 & 0,705 & 0,728 & 0,622 & 0,866 \\
\hline KPB4 & 0,707 & 0,793 & 0,691 & 0,857 \\
\hline KPB5 & 0,820 & 0,810 & 0,616 & 0,937 \\
\hline KPB6 & 0,823 & 0,801 & 0,644 & 0,947 \\
\hline KPB7 & 0,850 & 0,785 & 0,658 & 0,943 \\
\hline KPB8 & 0,711 & 0,749 & 0,633 & 0,841 \\
\hline & 19619 & Discrininant \\
\hline
\end{tabular}

Table 9:- Discriminant validity

Based on the table above, the DP1-DP7 indicator has a higher cross loading value for the DP construct, compared to other constructs, so it is concluded that the DP1-DP7 indicator has good discriminant validity. The same interpretation applies to other indicators.
Composite Reliability and Cronbach's Alpha

Besides the construct validity test, the construct reliability was also carried out as measured by composite reliability and Cronbach's alpha. The following are the results of the test:

\begin{tabular}{|c|c|c|}
\hline Variabel & $\begin{array}{l}\mathbf{C} \\
\mathbf{R}\end{array}$ & $\begin{array}{l}\text { Cronbac } \\
\text { h Alpha }\end{array}$ \\
\hline Desain Produk (DP) / Design Product & $\begin{array}{l}0,9 \\
84\end{array}$ & 0,981 \\
\hline Inovasi Produk (IP)/ Product Inovation & $\begin{array}{c}0,9 \\
66 \\
\end{array}$ & 0,956 \\
\hline $\begin{array}{l}\text { Keunggulan Bersaing Produk (KBP) ) / } \\
\text { Product Competitive Advantage }\end{array}$ & $\begin{array}{l}0,9 \\
67\end{array}$ & 0,961 \\
\hline $\begin{array}{l}\text { Kinerja Usaha }(\mathrm{K}) / \text { Business } \\
\text { Performance }\end{array}$ & $\begin{array}{l}0,9 \\
66\end{array}$ & 0,959 \\
\hline
\end{tabular}

Table 10:- Uji reliabilitas

The construct is declared reliable if it has a composite reliability value above 0.7 and Cronbach alpha above 0.7 . From the output results above, the constructs of DP, IP, $\mathrm{KBP}$, and $\mathrm{K}$ have composite reliability values above 0.7 and Cronbach's alpha above 0.7 . So it can be concluded that all constructs have good reliability.

\section{Q2 predictive relevance}

The Q-square value obtained using the R2 value in the table above by using the formula Q2 = 1- (1-R12) (1-R22), the following calculation results are obtained:

\begin{tabular}{|c|c|c|c|}
\hline Variabel & R Square & 1-R Square & \multirow{2}{*}{$\mathbf{Q}^{\mathbf{2}}$} \\
\cline { 1 - 3 } K & 0,469 & 0,531 & \multirow{2}{*}{0,902} \\
\cline { 1 - 3 } KBP & 0,816 & 0,184 & \\
\hline \multicolumn{3}{|c}{ Table $11:-\mathbf{Q}^{2}$ predictive relevance } \\
\hline
\end{tabular}

Based on the table above, the Q2 (Q-square predictive relevance) value obtained is 0.902 . Because the value is greater than 0 (zero), it means that the model has a predictive relevance value.

\section{$>$ Inner model evaluation}

The structural test in PLS is evaluated using R2 for the dependent variable and the path coefficient value for the independent variable which is then assessed for its significance based on the t-statistical value for each path. The structural research model can be seen in the following figure: 


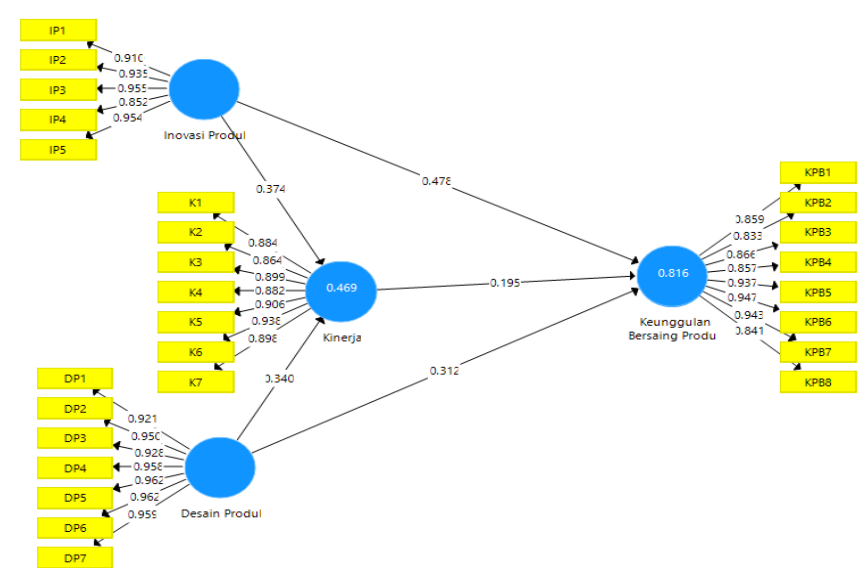

Fig 7:- Standardized model

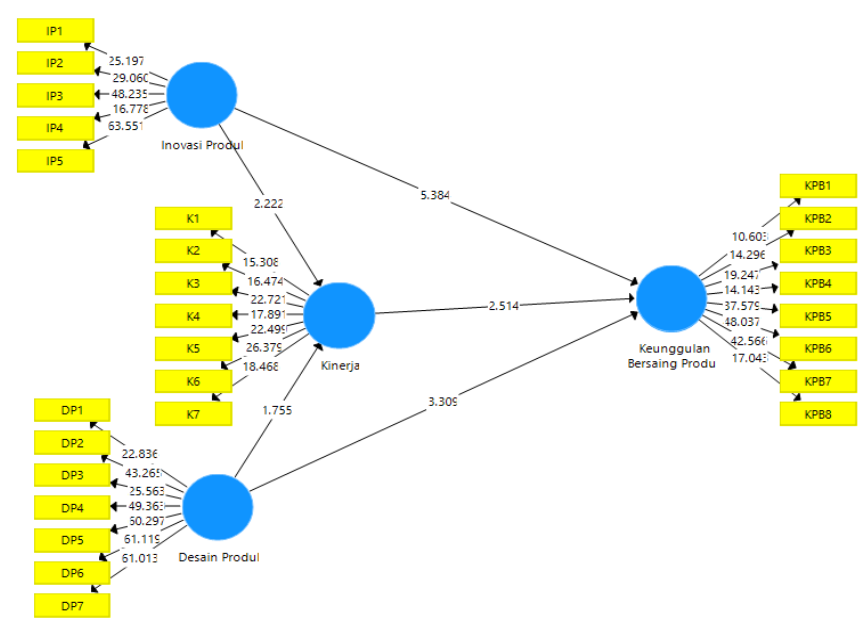

Fig 8:- Model t-value

Based on the Fig above, the equation obtained is as follows:

$\mathrm{K}=0.374 \mathrm{IP}+0.340 \mathrm{DP}, \mathrm{R} 2=0.469$

$\mathrm{KBP}=0.195 \mathrm{~K}+0.478 \mathrm{IP}+0.313 \mathrm{DP}, \mathrm{R} 2=0.816$

Based on this equation, it can be explained:

The value of R2 for the performance of MSMEs is 0.469 , meaning that the performance of MSMEs is influenced by Product Innovation and Product Design by $46.9 \%$, while the rest is influenced by other factors which are not examined in this study. In this case, it means that the work of MSMEs is strongly influenced by product innovation and makes product designs according to consumer or market expectations so that they can continue to compete against competitors.
Product innovation has a path coefficient of 0.374 with a positive direction, meaning that there is a positive influence between product innovation on the performance of MSMEs. If product innovation increases by 1 unit, the performance of MSMEs will increase by 0.374 and vice versa.

The product design has a path coefficient of 0.340 in a positive direction, which means that there is a positive influence on the performance of MSMEs. If the product design increases by 1 unit, the performance of MSMEs will increase by 0.340 and vice versa.

R2 value of Product Competitive Advantage is 0.816, which means that the Product Competitive Advantage is influenced by SME Performance, Product Innovation, and Product Design by $81.6 \%$ while the rest is influenced by other factors not examined in this study.

MSME performance has a path coefficient of 0.195 with a positive direction, meaning that there is a positive influence on the competitive advantage of the product. If the performance of MSMEs increases by 1 unit, the Competitive Advantage of the Product will increase by 0.195 and vice versa.

Product innovation has a path coefficient of 0.478 with a positive direction, meaning that there is a positive influence on the competitive advantage of the product. If the Product Innovation increases by 1 unit, the Product Competitive Advantage will increase by 0.478 and vice versa.

Product design has a path coefficient of 0.313 in a positive direction, meaning that there is a positive influence on the competitive advantage of the product. If the product design increases by 1 unit, the advantage will increase by 0.313 and vice versa.

Partial hypothesis test

Hypothesis:

Ho: there is no influence of the independent variable on the dependent variable

Ha: there is an effect of the independent variable on the dependent variable

Test criteria:

- Reject Ho if the p-value is $<0.05$

- Accept Ho if the p-value is $>0.05$

\begin{tabular}{|c|c|c|c|c|}
\hline Hipotesa & Pengaruh & Original Sample (O) & T Statistics (|O/STERR|) & p-value \\
\hline H1 & IP-K & 0,374 & 2,222 & 0,027 \\
\hline H2 & DP-K & 0,340 & 1,755 & 0,080 \\
\hline H3 & IP-KBP & 0,478 & 5,384 & 0,000 \\
\hline H4 & DP-KBP & 0,312 & 3,309 & 0,001 \\
\hline H5 & K-KBP & 0,195 & 2,514 & 0,012 \\
\hline
\end{tabular}

Table 12:- Uji Hipotesa Parsial 
Based on the table, it can be explained that:

$\mathrm{H} 1$ shows the meaning that product innovation has a positive influence on the performance of MSMEs. On the effect of product innovation on the performance of MSMEs, the $\mathrm{t}$ value obtained is 2.222 with a $\mathrm{p}$-value of 0.027. Because the p-value is $<0.05$, H1 is accepted, meaning that Product Innovation has a significant effect on the performance of MSMEs. Entrepreneurs can increase their business turnover by continuously increasing product innovation, meaning that the product has a model and shape in accordance with consumer expectations.

In testing the product design hypothesis on the performance of MSMEs, the $t$ value obtained is 1.755 with a p-value of 0.080 . Because the p-value is $>0.05, \mathrm{H} 2$ is rejected, meaning that the product design does not have a significant effect on the performance of MSMEs. This condition can also imply that the work results of MSMEs do not depend on product design.

The effect of product innovation on the competitive advantage of the product has a calculated $t$ value of 5.384 with a p-value of 0.000 . Because the $\mathrm{p}$-value is $<0.05, \mathrm{H} 3$ is accepted, meaning that product innovation is significant towards the competitive advantage of the product.

On the effect of product design on the competitive advantage of the product, the $t$ value obtained is 3.309 with a p-value of 0.001. Because the p-value <0.05, $\mathrm{H} 4$ is accepted, meaning that the product design has a significant effect on the competitive advantage of the product

In the relationship between MSME performance and competitive advantage, the calculated $t$ value obtained is 2.514 with a p-value of 0.012 . Because the p-value is $<0.05$, H5 is accepted, meaning that $\mathrm{K}$ provides a significant relationship with $\mathrm{KBP}$

\section{CONCLUSION}

Based on the table above, it can be concluded as follows:

$>$ In the relationship between IP and $\mathrm{K}$, the calculated $\mathrm{t}$ value is 2.222 with a p-value of 0.027 . Because the $\mathrm{p}$ value is $<0.05, \mathrm{H} 1$ is accepted, meaning that IP provides a significant relationship with $\mathrm{K}$

$>$ In the relationship between $\mathrm{DP}$ and $\mathrm{K}$, the $\mathrm{t}$ value obtained is 1.755 with a p-value of 0.080 . Because the $\mathrm{p}$-value is $>0.05, \mathrm{H} 2$ is rejected, meaning that DP does not provide a significant relationship with $\mathrm{K}$

$>$ In the relationship between IP and KBP, the calculated $\mathrm{t}$ value obtained is 5.384 with a p-value of 0.000 . Because the p-value is $<0.05, \mathrm{H} 3$ is accepted, meaning that IP provides a significant relationship with KBP

$>$ In the relationship between DP and KBP, the $t$ value obtained is 3.309 with a p-value of 0.001 . Because the p-value is <0.05, $\mathrm{H} 4$ is accepted, meaning that DP provides a significant relationship with KBP
In the relationship between $\mathrm{K}$ and $\mathrm{KBP}$, the calculated $\mathrm{t}$ value obtained is 2.514 with a p-value of 0.012 . Because the p-value is $<0.05, \mathrm{H} 5$ is accepted, meaning that $\mathrm{K}$ provides a significant relationship with KBP

\section{RECOMMENDATION}

Innovation MSMEs are expected to be able to carry out an innovation process so that product monotony does not occur, besides that it can produce innovative products, and can carry out organizational development and partnerships.

$>$ Competitive Advantage MSMEs are expected to be able to explore the uniqueness of their products, competitive prices in order to create healthy competition in the market.

\section{REFERENCES}

[1]. Eniola \& Ektebang (2015) https://cc.bingj.com/cache.aspx?q=Eniola+\%26+Ekte bang+(2015)

[2]. Kotler, P., \& Armstrong, G. (2016). Principle of Marketing (16th ed). North Carolina: Pearson Education Limited.

[3]. Kotler, Philip and Kevin Lane Keller. 2016. Marketing Management 15. Pearson Education, Inc.

[4]. Kuncoro, A. E. \& Riduwan. (2008). Cara Menggunakan dan Memaknai Analisis Jalur (Path Analysis). Bandung: Alfabeta.

[5]. Kusnendi (2008), Model-model Persamaan Struktural - Satu dan Multigrup Sampel dengan LISREL, Alfabeta, Bandung.

[6]. Sanusi, Anwar. 2014. Metodologi Penelitian Praktis Untuk Ilmu Sosial dan Ekonomi. Edisi Pertama. Cetakan Pertama. Penerbit Buntara Media, Malang.

[7]. Sekaran, Uma dan Roger Bougie (2010) Edisi 5, Research Method for Business: A Skill Building Approch. John Wiley @ Sons, New York.

[8]. Sugiyono. 2013. Metode Penelitian Kombinasi. CV Alfabeta. Bandung

[9]. Sunyoto, D. (2015). Keunggulan Bersaing. Jakarta: PT. Buku Seru.

[10]. Tjiptono, Fandy. 2012. Service Management Mewujudkan Layanan Prima, Edisi Kedua. Yogyakarta. Penerbit Andi

[11]. Wijanto, Setyo Hari (2008), Structural Equation Modeling dengan Lisrel 8.8: Konsep dan Tutorial, Edisi Pertama, Graha Ilmu, Yogyakarta.

[12]. Putri Wahyuningrum, dkk. Jurnal Manajemen dan Organisasi Vol V, No 2, Agustus 2014, Peningkatan Kinerja Usaha Kecil dan Menengah (UKM) Kluster Kerajinan di Kota Depok Menggunakan The House Model

[13]. Jurnal Konsep Bisnis dan Manajemen, Vol 3 No. 1 2017. KEUNGGULAN BERSAING MELALUI ORIENTASI PASAR DAN INOVASI PRODUK Muhammad Bukhori Dalimunthe 
[14]. Robbins, Stephen P. dan Mary Coulter. Alih bahasa oleh Bob Sabran dan Wibi, H,

[15]. (2010), Manajemen jilid 1 (edisi 10), Jakarta: Erlangga.

[16]. Kasali, R, (2010), MYLEN Mobilisasi Intangibles Menjadi Kekuatan Perubahan, Jakarta: Gramedia.

[17]. Kasali, R, (2010), MYLEN Mobilisasi Intangibles Menjadi Kekuatan Perubahan, Jakarta: Gramedia.

[18]. Kotler, Phillip. 2005. Manajemen Pemasaran : Analisis, Perencanaan, Implementasi, dan Kontrol Edisi Kesebelas. Alih Bahasa, Hendra Teguh. Jakarta : PT. Prenhallindo

[19]. Kotler, Philip dan Gary Amstrong. 2008. PrinsipPrinsip Pemasaran. Jilid 1. Edisi Kedua belas. Erlangga. Jakarta.

[20]. Kotler, Philip dan Kevin Lane Keller. 2009. Alih Bahasa : Benyamin Molan. Manajemen Pemasaran. Edisi Ketigabelas. Jilid 1. Cetakan Keempat. PT. Indeks. Jakarta.

[21]. Kotler, Philip dan Amstrong, Gary, (2014), Principles of Marketin, 12th Edition, Jilid 1 Terjemahan Bob Sabran Jakarta : Erlangga. 